\title{
Neutronic and Thermal-Hydraulic Safety Analysis for the Optimization of the Uranium Foil Target in the RSG-GAS Reactor
}

\author{
S. Pinem ${ }^{1}$, T.M. Sembiring ${ }^{1 *}$, P.H. Liem ${ }^{2}$ \\ ${ }^{I}$ Center for Nuclear Reactor Technology and Safety, National Nuclear Energy Agency \\ Puspiptek Area, Serpong, Tangerang Selatan 15310, Indonesia \\ ${ }^{2}$ Nippon Advanced Information Service (NAIS Co. Inc.), 416 Muramatsu, Tokaimura, Ibaraki 319-112, Japan
}

\section{ARTICLE INFO}

\section{Article history:}

Received 10 December 2015

Received in revised form 2 August 2016

Accepted 4 August 2016

\section{Keywords:}

Uranium foil target

Coupled neutronic and thermal-hydraulic code

Safety

RSG-GAS reactor

Mo-99

\begin{abstract}
A B S T R A C T
The G. A. Siwabessy Multipurpose Reactor (Reaktor Serba Guna G.A. Siwabessy, RSG-GAS) has an average thermal neutron flux of $2 \times 10^{14}$ neutron $/\left(\mathrm{cm}^{2} \mathrm{sec}\right)$ at the nominal power of $30 \mathrm{MW}$. With such a high thermal neutron flux, the reactor is suitable for the production of Mo-99 which is widely used as a medical diagnostic radioisotope. This paper describes a safety analysis to determine the optimum LEU foil target by using a coupled neutronic and thermal-hydraulic code, MTR-DYN. The code has been developed based on the three-dimensional multigroup neutron diffusion theory. The best estimated results can be achieved by using a coupled neutronic and thermal-hydraulic code. The calculation results show that the optimum LEU foil target is $54 \mathrm{~g}$ corresponding to the reactivity change of less than the limit value of $500 \mathrm{pcm}$. From the safety analysis for the case when the primary flow rate decreased by $15 \%$ from its nominal value, it was found that the peak temperatures of the coolant and cladding are $69.5^{\circ} \mathrm{C}$ and $127.9^{\circ} \mathrm{C}$, respectively. It can be concluded that the optimum LEU foil target can be irradiated safely without exceeding the limit value.
\end{abstract}

\section{INTRODUCTION}

The G. A. Siwabessy Multipurpose Reactor (Reaktor Serba Guna G.A. Siwabessy, RSG-GAS) is a material testing reactor (MTR) using beryllium as reflector and light water as moderator and coolant. The nominal power of $30 \mathrm{MW}$ (thermal) is generated by the 40 standard fuel elements (FEs) and eight control fuel elements (CEs) on the $10 \times 10$-core grid positions. The RSG-GAS reactor has 8 core grid positions of neutron flux trap to obtain a high thermal neutron flux. At the power of $30 \mathrm{MW}$, the average thermal neutron flux of $2 \times 10^{14}$ neutron $/\left(\mathrm{cm}^{2} \mathrm{~s}\right)$ can be achieved at all neutron flux trap positions. The RSG-GAS reactor is utilized mainly for radioisotope production of

* Corresponding author.

E-mail address: tagorms@batan.go.id

DOI: dx.doi.org/10.17146/aij.2016.532 medical and industry, such as ${ }^{99} \mathrm{Mo} /{ }^{99 \mathrm{~m}} \mathrm{Tc}$ using lowenriched uranium (LEU) targets, ${ }^{131} \mathrm{I}$ using $\mathrm{TeO}_{2}$ targets, ${ }^{153} \mathrm{Sm}$ using $\mathrm{Sm}_{2} \mathrm{O}_{3}$ target and ${ }^{153} \mathrm{Gd}$ using $\mathrm{Gd}_{2} \mathrm{O}_{3}$ targets [1].

The radioisotopes of molybdenum-99 and its decay product, technecium- $99 \mathrm{~m}$, are widely used in medical diagnostics for early and precise detection and treatment of diseases, such as heart condition and cancer [2,3]. In the years of 2008-2009, the shutdown of two out of the five major research reactors resulted in serious shortage supply of ${ }^{99} \mathrm{Mo}$. It became a global issue where many important diagnostic tests needed by patients were cancelled or delayed [3]. Since the ${ }^{99}$ Mo production should be produced by using LEU fuel targets, BATAN and ANL developed the LEU-foil target fabrication technique [4]. The LEU targets have been irradiated in the RSG-GAS and they showed an excellent results, therefore the technique was adopted for routine Mo-99 production in RSG-GAS. 
However, the application of the LEU targets based ${ }^{99} \mathrm{Mo}$ production requires optimization work. The optimization is aimed to obtain the maximum ${ }^{99}$ Mo production capacity while still fulfilling the safety limits. Safety analyses are therefore needed along with the optimization work.

This paper describes the aforementioned optimization work and safety analysis. In the past, there were several researches related to the safety analyses of the radioisotope (RI) target insertion using uncoupled neutronic and thermal-hydraulic (N/TH) analytical tools [5-10]. The use of a coupled $\mathrm{N} / \mathrm{TH}$ analytical tool is expected to improve the accuracy of the analysis results since the code simulates the real operation conditions and transients of a reactor. Coupled analytical tools are becoming common for reactor transient and dynamic analyses of as seen in these Refs. [11-16]. In this work, a coupled N/TH code based on threedimensional neutron diffusion theory, MTR-DYN code, is used for the present optimization and safety analyses. This code has previously also been used for transient analysis of the RSG-GAS reactor $[17,18]$.

\section{Reactor core and target descriptions}

The RSG-GAS has eight core grid positions for in-core irradiation with the dimension of $8.1 \mathrm{~cm} \times 7.71 \mathrm{~cm}$ per position as shown in Fig. 1 . The in-core positions serve as a neutron flux trap to obtain a high thermal neutron flux of $2 \times 10^{14}$ neutron $/\left(\mathrm{cm}^{2} \mathrm{~s}\right)$ at the nominal power of $30 \mathrm{MW}$. The in-core positions consist of one central irradiation position (CIP, four grids) and four irradiation positions (IP, one grid). The CIP can be used for larger targets' irradiation, such as a fuel bundle of power reactor, since it consists of four grids (equal to $16.2 \mathrm{~cm} \times 15.42 \mathrm{~cm}$ ). In the present study, the four IPs (B-6, D-9, E-4 and G-7) and four core grid positions of CIP (D-6, D-7, E-6 and E-7) are used for the LEU foil targets.

The target is an LEU metal foil with the dimension of $7.6 \mathrm{~cm} \times 8.8 \mathrm{~cm} \times 1.25 \times 10^{-2} \mathrm{~cm}$ and uranium enrichment of $19.8 \%$ w/o. The LEU foil is enveloped by $1.5 \times 10^{-3} \mathrm{~cm}$ thick nickel foil and placed between two aluminum tubes that are welded from both ends. The inner aluminum tube has inner and outer diameters of $2.621 \mathrm{~cm}$ and $2.799 \mathrm{~cm}$, respectively, while the outer tube has inner and outer diameters of 2.822 and $3.0 \mathrm{~cm}$, respectively. The length of the $\mathrm{Al}$ tubes is $16.2 \mathrm{~cm}$. The maximum weight of LEU target per tube is $3.0 \mathrm{~g}$.

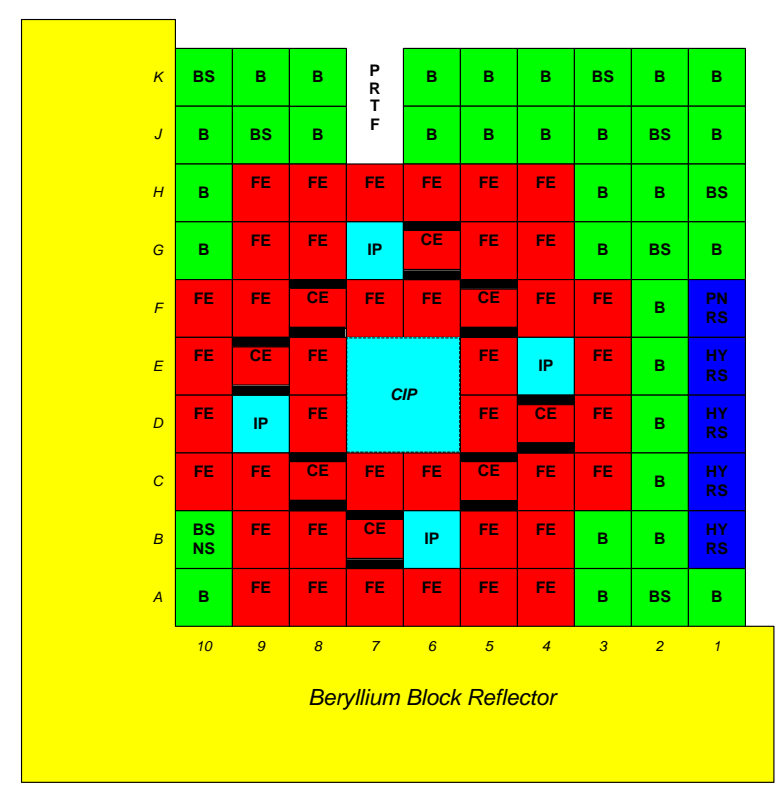

Notes : FE = Standard Fuel Element, $\mathrm{CE}=$ Control Fuel Element, $\mathrm{BE}=$ Be Reflector Element, BS = Be Reflector Element with plug, IP = Irradiation Position, CIP = Central Irradiation Position, PNRS = Pneumatic Rabbit System, HYRS = Hydraulic Rabbit System (burn-up classes are in the second raw)

Fig. 1. Typical working core of the RSG-GAS.

The target will be inserted to a rig that can accommodate a maximum of three targets. Before being irradiated in the core, the rig is placed into a stringer, as shown in Fig. 2, and is inserted to an IP or CIP. Hence one IP or CIP can be occupied by nine targets at maximum.

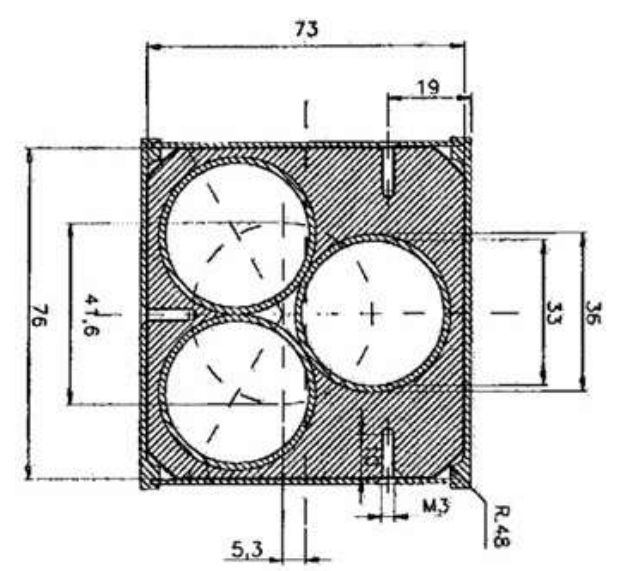

Fig. 2. Stringer for irradiation of LEU foil target (units are in $\mathrm{mm}$ ).

\section{EXPERIMENTAL METHODS}

In optimizing the target, we assumed that the core is utilized for a single target of the LEU foil. Since the target gives a positive reactivity, the optimum capacity with a nonfissionable target is quite simple, i.e., by doing a balance reactivity to get the minimum reactivity effect. The determination of the optimum LEU foil target 
in the RSG-GAS reactor is important in the reactor utilization especially for irradiating mixed fissionable and nonfissionable targets.

\section{Cell calculations}

The first step is the cell calculations to generate group constants of the LEU foil targets. The cell calculations were carried out by WIMSD5B code [19]. Since the MTR-DYN code uses a finite difference method for spatial variables, the target is homogenized based on the configuration of stringer as shown in Fig. 2. A core grid position of IP or CIP can be divided into 3 zones radially, i.e. two zones of $1 / 4$ (Model-1) and a zone of $1 / 2$ (Model-2) of one core grid position, as shown in Fig. 3. Finally, as seen in Fig. 4, the typical working core (Fig. 1) can be modeled using homogenized zones of IPs and CIP. Table 1 shows the axial compositions of homogenized zones for the cell calculations. The cell calculations were carried out for the cases of 1,2 , and 3 LEU foil targets in one rig.

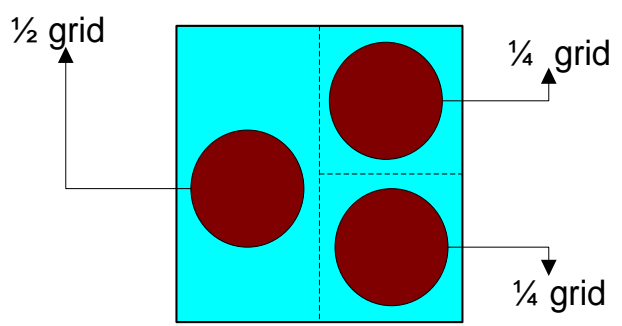

Fig. 3. The homogenized zones based on the stringer of LEU foil target.

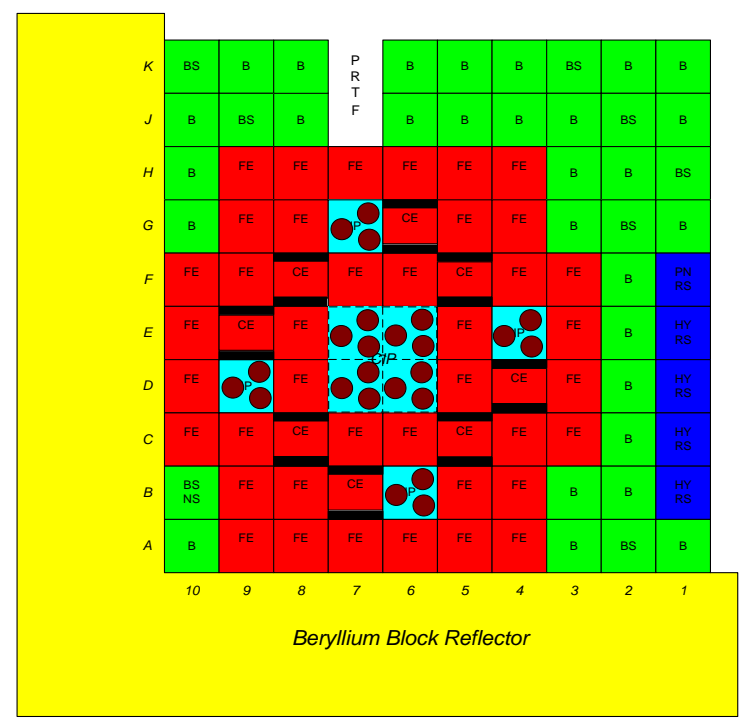

Notes : FE = Standard Fuel element, $\mathrm{CE}=$ Control Fuel Element, $\mathrm{BE}=$ Be Reflector Element, BS = Be Reflector Element with plug, IP = Irradiation Position, CIP = Central Irradiation Position, PNRS = Pneumatic Rabbit System, HYRS = Hydraulic Rabbit System

Fig. 4. Typical working core of the RSG-GAS with the homogenized target zones.
Table 1. Dimension and material of 1, 2 and 3 LEU foil targets

\begin{tabular}{|c|c|c|}
\hline Cell & Height, $\mathrm{cm}$ & Materials \\
\hline Upper Part & 3.7 & $\begin{array}{l}\mathrm{H}_{2} \mathrm{O} \text { and } \mathrm{Al} \text { (rig, inner and } \\
\text { outer tubes) }\end{array}$ \\
\hline Active Part & 8.8 & $\begin{array}{l}\mathrm{H}_{2} \mathrm{O}, \mathrm{Al} \text { (rig, inner and } \\
\text { outer tubes), } \\
\text { LEU metal and } \mathrm{Ni}\end{array}$ \\
\hline Lower Part & 3.7 & $\begin{array}{l}\mathrm{H}_{2} \mathrm{O} \text { and } \mathrm{Al} \text { (rig, inner and } \\
\text { outer tubes) }\end{array}$ \\
\hline Rig part & $\begin{array}{l}43.8 \text { (1 target) } \\
27.6 \text { ( } 2 \text { targets }) \\
11.4 \text { (3 targets) }\end{array}$ & $\mathrm{H}_{2} \mathrm{O}$ and $\mathrm{Al}$ \\
\hline
\end{tabular}

\section{Optimization of LEU foil targets}

The optimization was carried out by the following steps:

1. Determination of the excess reactivity change due to the inserted position and the mass of targets for Model 1 (1/4 grid) and Model 2 (1/2 grid). This step is needed to arrange the targets which give the maximum mass of LEU foil. In this step we used a two-dimensional multigroup neutron diffusion method code, BATAN-FUEL [20]. The LEU foil target is inserted in the E-7 core grid position.

2. Determination of the excess reactivity change due to the maximum LEU foil target per core grid position by using BATAN-FUEL code, for each IP and CIP. We assumed that the mass of target was $27 \mathrm{~g}$ in a core grid position of IP and CIP. Similar to the step 1, the maximum mass of LEU foil target in the IP and CIP can be determined by considering the excess reactivity change limit of $500 \mathrm{pcm}$.

3. Determination of the temperature of target and fuel as a function of the control rod insertion $30 \mathrm{~cm}$ for safety analysis. In a previous study, the maximum axial power peaking factor occurred at the insertion of $30 \mathrm{~cm}$ [21]. The optimum target arrangement, obtained from step 2, is evaluated by using the MTR-DYN, with three-dimensional core model. The temperature limits for cladding and $\mathrm{H}_{2} \mathrm{O}$ are $450^{\circ} \mathrm{C}$ and $90^{\circ} \mathrm{C}$, respectively. If the core arrangement could not fulfill the limit, the target should be rearranged.

4. Accident analysis where the flow rate is decreased by $15 \%$ of its nominal value. This is commonly called a loss of flow accident (LOFA). In this step, the adequate coolability of fuels and targets is analyzed by using the MTR-DYN code. The temperature limits are same as in step 3. 
It is noted that the target rearrangement can be carried out by either reposition of target or reduction of the target's mass.

\section{RESULTS AND DISCUSSION}

From Table 2, it can be observed that Model-2 (1/2 grid) has a lower value of reactivity change but a higher heat generation, compared to Model-1. For all models, a higher target mass gives higher reactivity change and heat generation. The lower reactivity changes in the Model-2 are attributed to the higher atomic ratio of $\mathrm{H}$ (in the water) and ${ }^{235} \mathrm{U}$ (in the LEU foil), since the volume of water in the Model-2 is significantly larger than Model-1. The higher heat generation with higher mass of ${ }^{235} \mathrm{U}$ can be understood since the fission reaction rate is directly proportional to mass of ${ }^{235} \mathrm{U}$. These results show that the targets should be inserted prior to the $1 / 2$ grid position (Model-2) of the IPs and the CIPs, since it has a relatively smaller reactivity change.

Table 2. Reactivity change and heat generation due to LEU foil target insertion

\begin{tabular}{cccccc}
\hline \multirow{2}{*}{$\begin{array}{c}\text { Mass of } \\
{ }^{235} \mathrm{U}(\mathrm{g})\end{array}$} & $\begin{array}{c}\text { The } \\
\text { number } \\
\text { of foil }\end{array}$ & \multicolumn{2}{c}{$\begin{array}{c}\text { Reactivity changes } \\
(\mathrm{pcm})\end{array}$} & \multicolumn{2}{c}{$\begin{array}{c}\text { Heat generation } \\
(\mathrm{kW})\end{array}$} \\
\cline { 3 - 6 } & & Model-1 & Model-2 & Model-1 & Model-2 \\
\hline 3 & 1 & 62.1 & 14.5 & 18.4 & 20.7 \\
6 & 2 & 110.4 & 73.1 & 37.5 & 41.5 \\
9 & 3 & 153.7 & 133.8 & 55.4 & 63.5 \\
\hline
\end{tabular}

In the actual RSG-GAS operation, control rod (CR) positions change from the beginning of cycle (BOC) to the end of cycle (EOC). In this study, the $\mathrm{CR}$ insertion positions for BOC and EOC were set to $30 \mathrm{~cm}$ and $0 \mathrm{~cm}$ (fully up), respectively. Figure 5 shows the axial distributions of maximum temperature in the FE meat for the case of $9 \mathrm{~g} \mathrm{LEU}$ foil target inserted into CIP (E-7 core grid position). The figure shows that the effect of $\mathrm{CR}$ position of $30 \mathrm{~cm}$ is quite significant compared to the CR position of $0 \mathrm{~cm}$. The target insertion increases the maximum temperature by approximately $7.16^{\circ} \mathrm{C}$ for the $\mathrm{CR}$ insertion case of $30 \mathrm{~cm}$, however the temperature only increases by $0.33^{\circ} \mathrm{C}$ when the insertion of CR is $0 \mathrm{~cm}$.

As shown in Fig. 6, the CR position does not strongly affect the maximum temperature since the difference is only about $0.7^{\circ} \mathrm{C}$. Figures 5 and 6 show that higher temperatures occur at the BOC since CRs must be inserted to up to half of the active core.

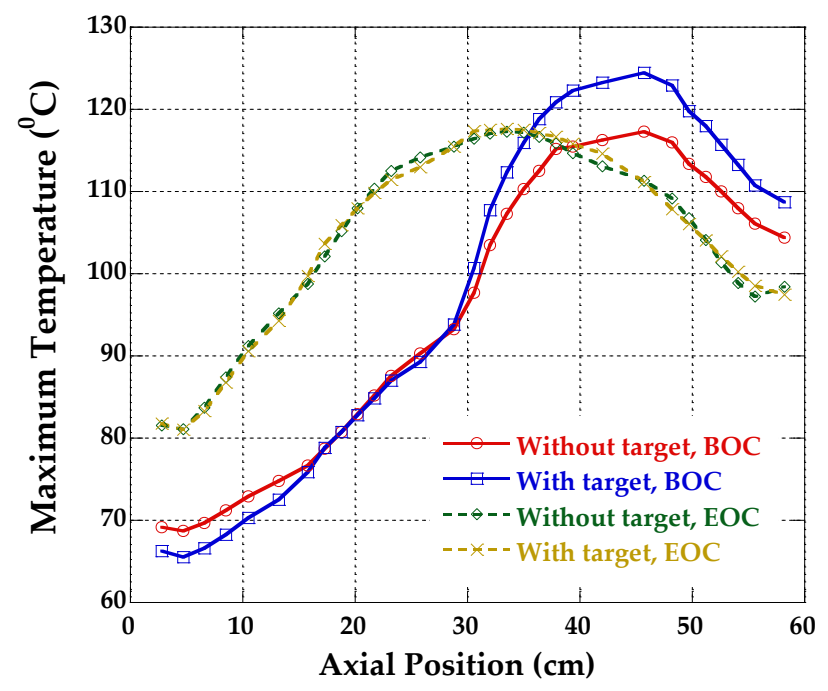

Fig. 5. The axial distribution of maximum temperature in the meat at the FE.

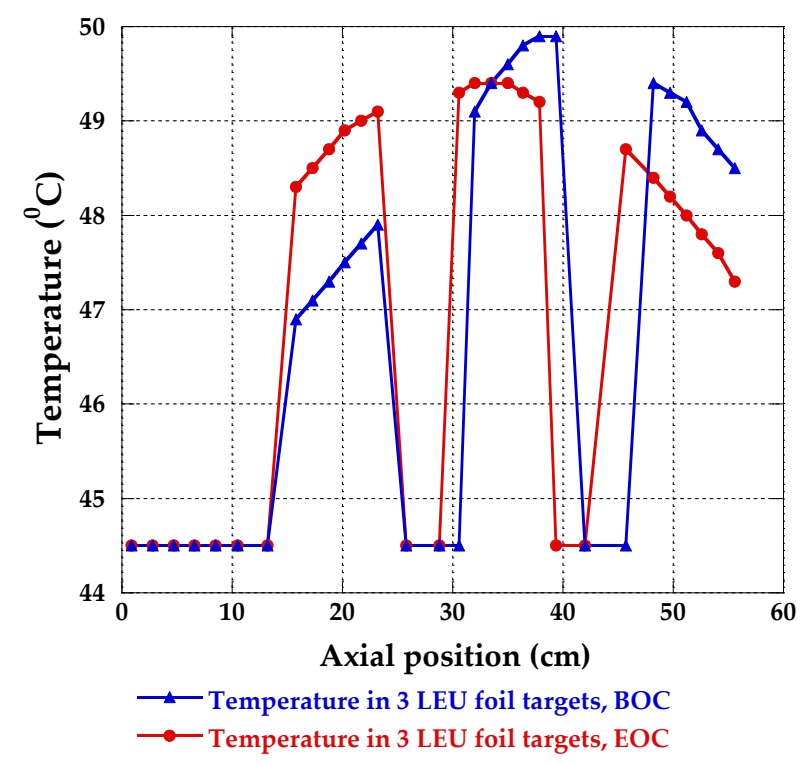

Fig. 6. The axial temperature in the 3 LEU foil targets.

The core calculations showed that the optimum LEU foil target can be achieved by using IP core grid position since the gradient of reactivity change is smaller than the one of the CIP (cf. Fig. 7). A fully occupied IP/CIP core grid position is equal to $27 \mathrm{~g}$ LEU foil target (nine targets). Figure 7 shows that the LEU foil target can be optimized in an IP up to $54 \mathrm{~g}$, while in the CIP up to $33.75 \mathrm{~g}$. The higher reactivity change in the CIP is attributed to the higher neutron importance in the core center.

The safety analysis was carried out for the optimum target of $54 \mathrm{~g}$ by using MTR-DYN code and the core was modeled by threedimensional full core geometry. As shown in Fig. 8, the calculated peak temperatures after $0.5 \mathrm{~s}$ reactor scram due to $15 \%$ primary system flow reduction 
(LOFA), i.e., the coolant, cladding, and fuel meat maximum temperatures are found to be $69.5^{\circ} \mathrm{C}, \quad 127.9^{\circ} \mathrm{C}$, and $128.9^{\circ} \mathrm{C}$, respectively. The temperature increases from initial condition are about $1.3^{\circ} \mathrm{C}, 2.3^{\circ} \mathrm{C}$, and $2.3^{\circ} \mathrm{C}$ for coolant, cladding, and fuel, respectively. All temperatures are lower than the limit values and the LOFA consequence is not severe.

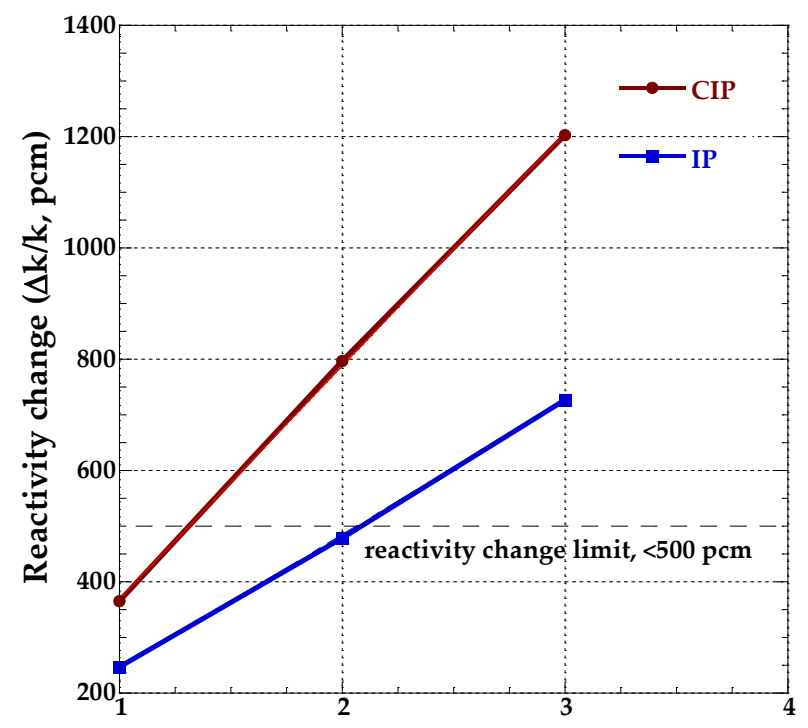

Number of fully target core grid positions

Fig.7. The reactivity changes due to the fully target at CIP and IP.

Compared to the reactivity changes, the maximum temperature changes are sensitive to the targets' position and mass of ${ }^{235} \mathrm{U}$ as seen in Table 3 . The maximum cladding temperature of $125.6^{\circ} \mathrm{C}$ is much lower than the limit value of $450^{\circ} \mathrm{C}$, as well as the maximum coolant temperature is less than limit value of $90^{\circ} \mathrm{C}$. It can be concluded that the optimum of $54 \mathrm{~g}$ LEU targets can be irradiated safely. However, in the on-power insertion, an unintentional drop of a target must be avoided since the induced reactivity insertion rate is too high, that is about $308 \mathrm{pcm} / \mathrm{s}$.

Table 3. Maximum temperatures as a function of the targets' position and mass of ${ }^{235} \mathrm{U}$

\begin{tabular}{|c|c|c|c|c|c|c|}
\hline \multirow{2}{*}{ No. } & \multirow{2}{*}{$\begin{array}{l}\text { Mass of } \\
{ }^{235} \mathrm{U}(\mathrm{g})\end{array}$} & \multirow{2}{*}{$\begin{array}{c}\text { Position of } \\
\text { target }\end{array}$} & \multirow{2}{*}{$\begin{array}{c}\text { Axial Power } \\
\text { Peaking } \\
\text { Factor }\end{array}$} & \multicolumn{3}{|c|}{ Maximum temperature $\left({ }^{\circ} \mathrm{C}\right)$} \\
\hline & & & & Fuel & Cladding & Coolant \\
\hline 1 & 0 & - & 1.76 & 123.78 & 122.79 & 67.35 \\
\hline 2 & 27 & IP (B-6) & 1.76 & 125.37 & 124.39 & 67.41 \\
\hline 3 & 54 & IP (B-6, G-7) & 1.76 & 126.62 & 125.64 & 68.03 \\
\hline 4 & 27 & CIP (E-7) & 1.76 & 125.93 & 124.93 & 67.82 \\
\hline
\end{tabular}

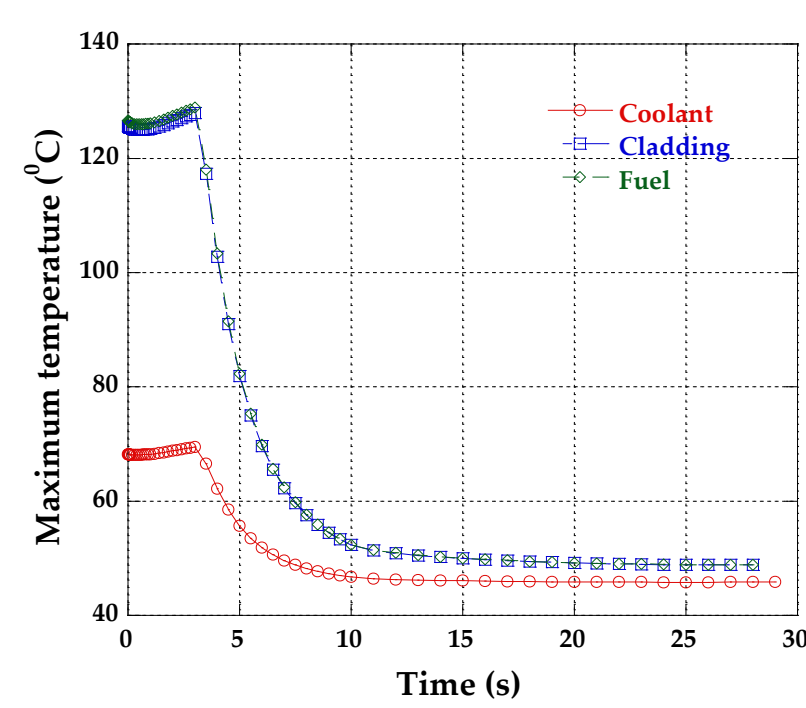

Fig. 8. Peak temperature after the primary flow decrease of $85 \%$.

\section{CONCLUSION}

Target optimization and safety analyses by using a coupled neutronic and thermal hydraulic code have been carried out to obtain the maximum LEU foil target mass for the ${ }^{99}$ Mo production in the RSG-GAS reactor. The analyses results showed that the maximum LEU foil target of $54 \mathrm{~g}$ can be irradiated in the RSG-GAS reactor without violating any safety limits (i.e., the cladding and coolant temperatures are lower than limit values). For the on-power target insertion, the target handling must be designed to prevent an unintentional target drop event.

\section{REFERENCES}

1. S. Pinem, J. Susilo and T.M. Sembiring, Journal of Indonesian Technology 35 (2012) 37. (in Indonesian)

2. M. Ahmad, G. Vandegrift and P. Cristini, Science and Technology of Nuclear Installations 2014 (2014) 1.

3. Anonymous, The Mo-99 Global Shortage: A closer look at industry challenges, September (2009).

http://nps.cardinal.com/nps/thelink/issues/923 2009.asp. Retrieved in November (2015).

4. E. Bradley, K. Alldred, P. Adelfang et al., IAEA activities to support the transition of molybdenum-99 production away from the use of highly enriched uranium, Proceedings of the International Meeting on Redced Enrichment for Research and Test Reactors (2010) 35. 
5. M.Q. Huda, M.S. Islam, M.M. Rahman et al., Ann. Nucl. Energy 36 (2009) 199.

6. S. Forughi, S. Hamidi, H. Khalafi et al., Ann. Nucl. Energy 57 (2013) 16.

7. A. Mushtaq, M. Iqbal, I. Hussain et al., Ann. Nucl. Energy 35 (2008) 345.

8. B. Meftah, Ann. Nucl. Energy 33 (2006) 1164.

9. N. Salek, M. Jamre, L.B. Moghaddam et al., Ann. Nucl. Energy 40 (1) (2012) 194.

10. B.El. Bakkari, B. Nacir, T.El. Bardouni et al., Ann. Nucl. Energy 78 (2015) 140.

11. Y. Kozmenkov, S. Kliem and U. Rohde, Ann. Nucl. Energy 84 (2015) 153.

12. R. Pericas, K. Ivanov, F. Reventós et al., Ann. Nucl. Energy 87 (2016) 366.

13. J. Zhou, D. Zhang, S. Qiu et al., Nucl. Eng. Des. 282 (2015) 93.
14. W.T. Kouidri, F. Letaim, A. Boucenna et al., Prog. Nucl. Energy 85 (2015) 384.

15. A. Rosenkrantz, M. Avramova, K. Ivanov et al., Ann. Nucl. Energy 73 (2014) 122.

16. K. Ivanov, E. Sartori, E. Royer et al., Nucl. Technol. 157 (2007) 177.

17. S. Pinem, T.M. Sembiring and Setiyanto, Journal of Nuclear Reactor Technology Tri Dasa Mega 11 (2009) 153. (in Indonesian)

18. I. Kuntoro, S. Pinem and T.M. Sembiring, Journal of Nuclear Reactor Technology Tri Dasa Mega 12 (2010) 64. (in Indonesian)

19. Anonymous, OECD/NEA Data Bank Documentation. Package ID No. 1507/02, WIMS-D5 (1998).

20. P.H. Liem, Atom Indonesia 22 (1996) 67.

21. Anonymous, Safety Analysis Report of RSGGAS Reactor, Rev. 10, National Atomic Energy Agency (2008). (in Indonesian) 